\title{
19. GEOCHEMISTRY OF CHLOROPHYLL DERIVATIVES: DEEP SEA DRILLING PROJECT LEG 61, SITE 462, NORTHERN NAURU BASIN ${ }^{1}$
}

\author{
Earl W. Baker and J. William Louda, Organic Geochemistry Group, College of Science, \\ Florida Atlantic University, Boca Raton, Florida
}

\section{INTRODUCTION}

Six core-samples from DSDP/IPOD Site 462 in the Central Nauru Basin were examined for tetrapyrrole pigment content. Samples ranged from Pliocene to middle Cretaceous, and were recovered from 25 to 551 meters sub-bottom.

The fate of chlorophyll in an open ocean environment was to be the prime objective of this study. Leg 61 is viewed as an extension of tetrapyrrole pigment studies in the western and southwestern Pacific which included the Japan Trench sites of Legs 56-57 (Louda et al., in press; Baker and Louda, in press a), the Shikoku Basin and Daito Ridge sites of Leg 58 (Baker and Louda, 1980), and the Mariana Basin and Trench sites of Leg 60 (Baker and Louda, in press b). Throughout these studies, we have detected tetrapyrrole pigments which by their quantity and quality could be related to the overall productivity of overlying waters, depositional environments, and certain geologic events, such as reworking. The more-oceanic position of Site 462 and suspected turbidite deposition in the deep ocean basin in which it is situated seemed favorable for relating rate of pigment loss to oxic diagenesis.

\section{PROCEDURES}

One hundred twenty-five to 200 grams of each core-sample was cleaned of possible surface contamination and oxidation products by scraping, and exhaustively extracted with acetone:methanol $(9: 1) \mathrm{v} / \mathrm{v})$ on a ball mill. Solvent was removed in vacuo and soluble organics transferred to ethyl ether by salting out of the remaining aqueous phase. Extracts in ether were washed with brine, then repeatedly with distilled water, and the ether was removed with a gentle stream of dry nitrogen. Quantity and type of tetrapyrrole pigments were determined by electronic spectroscopy of the crude extract in tetrahydrofuran (THF) solvent. Free-base porphyrins were tested for by extraction of an ethereal solution with $10 \% \mathrm{HCl}(\mathrm{w} / \mathrm{v})$ and examination of the aqueous acid hypophase with an ultraviolet lamp $\left(\lambda_{\max }=356-366\right.$ $\AA)$. The detection of free-base porphyrin by dication fluorescence is extremely sensitive, with a limit below $5 \mathrm{ppb}$, relative to an initial 100-g sediment sample (see Baker and Smith, 1977).

\section{RESULTS AND DISCUSSION}

Table 1 lists the sections from which samples were taken for analysis for tetrapyrrole pigments. Only in Section 462-54-2 was any hint of the presence of an intact tetrapyrrole chromophore noticed. The visible spectrum of the total extract from Section 462-54-2, when dissolved in $0.5 \mathrm{ml}$ THF and scanned with the range set

\footnotetext{
${ }^{1}$ Initial Reports of the Deep Sea Drilling Project, Volume 61.
}

at 0-0.2 AUFS (Absorption Units-Fuli Scale), indicated trace free-base porphyrin, or about $0.08 \mathrm{ng}$ total pigment, well below the quantity required for further analysis. Only with the extract from Section 462-54-2 was a positive fluorescence check obtained.

The dearth of tetrapyrrole pigments in open-ocean sedimentary environments has to date been the rule. This, of course, is related to lack of productivity in the overlying waters. Probable oxic deposition and redeposition, since basin sediments at Site $\mathbf{4 6 2}$ are listed as turbidite sequences from adjacent structural highs (Site Summary, this volume), has apparently led to a complete removal of any remaining chlorophyll derivatives from the fossil record.

It is of interest, however, to correlate with suspected geologic events the presence of an extremely minute amount of free-base porphyrin in the Cretaceous sediments of Section 462-54-2. Sediments of the Cenomanian-Turonian strata of Site 462 are believed to have been deposited during a time of relative anoxicity, and so would in part be similar in diagenetic history to the Cretaceous layers of the Atlantic basins (Site Summary, this volume; Larson, Schlanger, et al., 1978), though obviously not as rich. The proximity of underlying volcanic complexes to sections 54-2, and 59-1, leading to thermal alteration of any preserved organic matter in those strata, has been reported (Larson, Schlanger, et al., 1978; Site Summary, this volume). Although we were unable to detect any porphyrins in Section 59-1, probably because of this extreme thermal alteration, the hint of porphyrin in Section 54-2, seems to indicate that initially there had been some preservation of organic matter during the late Cretaceous at Site 462 . The thermal stability of porphyrins is relatively good compared with most biologic markers, as discussed previous for DSDP sediment samples (see Baker et al., 1977).

\section{CONCLUSIONS}

The post-Cretaceous sediments obtained from DSDP/ IPOD Site 462 were determined to be essentially devoid of chlorophyll derivatives. This dearth of tetrapyrrole pigment is attributed to low productivity in the openocean environment and to oxidative diagenesis compounded by turbidite resedimentation. An Upper Cretaceous sample (from Section 462-54-2) yielded only trace amounts of unidentifiable free-base porphyrins. The volcanism in close proximity to these strata unfortunately prevents any valid assessment of possible Cretaceous anoxic preservation of chlorophyll derivatives at Site 462 . 
Table 1. Sample description and tetrapyrrole pigments: DSDP Leg 61, Site 462.

\begin{tabular}{|c|c|c|c|c|c|c|}
\hline Section Sampled & $\begin{array}{c}\text { Depth } \\
\text { Sub-bottom a } \\
\text { (m) }\end{array}$ & Chronostratigraphy ${ }^{a}$ & Lithologic Description $^{a}$ & $\begin{array}{l}\text { Organiç } \\
\text { Carbon } \\
\text { (wt. \%) }\end{array}$ & $\begin{array}{l}\text { Organic } \\
\text { Carbonc } \\
\text { (wt. \%) }\end{array}$ & $\begin{array}{l}\text { Tetrapyrrole } \\
\text { Pigments }\end{array}$ \\
\hline $462-3-4$ & 25.0 & Pleistocene/Pliocene & Yellow-brown radiolarian ooze & 0.133 & 0.16 & None \\
\hline $462-7-5$ & 64.5 & Upper Pliocene & Gray-white nannofossil-foraminiferal ooze & 0.034 & 0.07 & None \\
\hline $462-17-4$ & 158.0 & Lower Miocene & Gray-orange nannofossil ooze & 0.032 & - & None \\
\hline $462-49-4$ & 462.0 & Maestrichtian & Greenish black siltstone-limestone & 0.048 & 0.19 & None \\
\hline $462-54-2$ & 511.0 & Campanian & Light olive-gray limestone & 0.030 & 0.07 & $\begin{array}{l}\text { Trace, free-base } \\
\text { porphyrin }\end{array}$ \\
\hline $462-59-1$ & 550.5 & Middle Cretaceous & Pale brown zeolitic mudstone & 0.032 & 0.04 & None \\
\hline
\end{tabular}

a From Site Summary, this volume.

b From DSDP on-shore laboratory results for sediment size, carbon/carbonate; nearest sample.

c From Phillips Petroleum, Bartlesville, Oklahoma (K. S. Schorno); same sample.

$\mathrm{d}$ Free-base porphyrin detected by acid extraction and dication fluorescence. (Limit of detection: 5 ppb with $100-\mathrm{g}$ sample size).

\section{ACKNOWLEDGMENTS}

These studies were funded by a National Science Foundation grant (\#OCE-791-3258). Ms. Patricia Avery is thanked for initial sample preparation. Drs. E. H. Man and P. P. Zelmer are thanked for their reviews of the manuscript.

\section{REFERENCES}

Baker, E. W., and Louda, J. W., 1980. Geochemistry of tetrapyrrole pigments in sediments of the north Philippine Sea, Deep Sea Drilling Project Leg 58. In Klein, G. deV., Kobayashi, K., et al., Init. Repts. DSDP, 58: Washington (U.S. Govt. Printing Office), 737740.

, in press a. Chlorophyll diagenesis in Japan Trench sediments, Deep Sea Drilling Project Sites 438, 439, and 440. In Scientific Party, Init. Repts. DSDP, 56, 57, Pt. 2: Washington (U.S. Govt. Printing Office).
, in press b. Chlorophyll derivatives in sediments in the south Philippine Sea, Deep Sea Drilling Project Leg 60. In Hussong, D., Uyeda, S., et al., Init. Repts. DSDP, 60: Washington (U.S. Govt. Printing Office).

Baker, E. W., Palmer, S. E., and Huang, W. Y., 1977. Intermediate and late diagenetic tetrapyrrole pigments, Leg 41: Cape Verde Rise and Basin. In Lancelot, Y., Seibold, E., et al., Init. Repts. DSDP, 41: Washington (U.S. Govt. Printing Office), 825-837.

Baker, E. W., and Smith, G. D., 1977. Fossil porphyrins and chlorins in deep ocean sediments. In Yen, T. F. (Ed.), Chemistry of Marine Sediments: Ann Arbor (Ann Arbor Sci. Publ.), pp. 73-79.

Larson, R. L., Schlanger, S., et al., 1978. Volcanic complex found. Geotimes, 23, no. 12:21-24.

Louda, J. W., Palmer, S. E., and Baker, E. W., in press. Early products of chlorophyll diagenesis in Japan Trench sediments of Deep Sea Drilling Project Sites 434, 435, and 436. In Scientific Party, Init. Repts. DSDP, 56, 57, Pt. 2: Washington (U.S. Govt. Printing Office). 